the relatively small number of Asian children with active tuberculosis. The further analysis of our data by Dr Vickers is valid, but does not detract from our conclusion that tuberculosis was more common in poor children than in Asian children.

\section{Ribavirin in respiratory syncytial virus infection}

Sir,

Over the winter of 1988, 10 infants with congenital heart disease were treated for severe bronchiolitis at Guy's Hospital. All required respiratory support of greater than $50 \%$ oxygen in a headbox, and seven required assisted ventilation. Seven patients were positive for respiratory syncytial virus, and seven received nebulised ribavirin for three to five days. There were four deaths, all infants with pre-existing pulmonary hypertension (see table).

Despite the early use of nebulised ribavirin, supervised by Brittania Pharmaceuticals Ltd, some patients continued to deteriorate. Only three patients showed some improvement after ribavirin use. No patient improved when ribavirin was first used after ventilation had commenced. Indeed one child had an unexplained cardiorespiratory collapse on the ventilator shortly after starting ribavirin. We documented no other possible side effects.

We wish to emphasise the severity in Britain of respiratory syncytial virus bronchiolitis in infants with congenital heart disease. The high mortality in the presence of pulmonary hypertension confirms earlier American reports. ${ }^{1}$ Our clinical impression was that ribavirin, started very early in the disease 'may' prevent some infants progressing to respiratory failure. The outcome was never one of dramatic clinical improvement.

The resource implications of widespread early use of ribavirin in all mildly symptomatic infants are very great however (approximately $£ 600$ for a three day course). We therefore strongly support the call for randomised controlled trials of ribavirin in bronchiolitic infants with cardiopulmonary disease. ${ }^{2}$

\section{References}

1 MacDonald NE, Hall CB, Suffin SC, Alexson C, Harris PJ, Manning JA. Respiratory syncitial virus infection in infants with congenital heart disease. $N$ Engl J Med 1982;307:397-400.

2 Isaacs D, Moxon ER, Harvey D, et al. Ribavirin in respiratory syncitial virus infection. A double blind placebo controlled trial is needed. Arch Dis Child 1988;63:986-7.

M Sharland, N Whitehouse, and S Qureshi Guy's Hospital, St Thomas Street, London SE1 9RT

\section{Lung function and bronchial responsiveness measured by forced oscillometry after bronchopulmonary dysplasia}

Sir,

We were interested to read the recent report by Duiverman et al on lung function in the long term survivors of bronchopulmonary dysplasia. ${ }^{1}$ Their results differ from those of previous small studies and one large series ${ }^{2}$ in that they failed to find an increase in airway responsiveness to inhaled histamine. Although differences in protocols and techniques used in these studies make direct comparison difficult, we feel that the main problem was technical rather than physiological.

The incidence of a positive airway response to pharmacological challenge depends on the arbitrary dose or concentration of the bronchoconstrictor agent used. By choosing a histamine dose as low as $1 \mu \mathrm{mol}(325 \mu \mathrm{g})$, Duiverman and colleagues found very few responders both in the uncomplicated preterm survivors and in the group with bronchopulmonary dysplasia. At such a dose, only those who had a degree of airway responsiveness comparable with clinical asthma would be identified. One can only infer from their study that long term survivors of bronchopulmonary dysplasia were no more likely than other children of preterm birth to have a degree of airway

Table Clinical details of 10 infants studied

\begin{tabular}{|c|c|c|c|c|c|}
\hline $\begin{array}{l}\text { Case } \\
\text { No }\end{array}$ & $\begin{array}{l}\text { Congenital } \\
\text { heart } \\
\text { disease }\end{array}$ & $\begin{array}{l}\text { Respiratory } \\
\text { syncytial } \\
\text { virus }\end{array}$ & $\begin{array}{l}\text { Assisted } \\
\text { ventilation } \\
\text { given }\end{array}$ & $\begin{array}{l}\text { Ribavirin } \\
\text { given }\end{array}$ & Outcome \\
\hline 1 & Total anomalous pulmonary venous drainage & + & Yes & Yes & Died \\
\hline 2 & Patent ductus arteriosus & + & Yes & Yes & Alive \\
\hline 3 & Double outlet right ventricle & + & Yes & Yes & Died \\
\hline 4 & Total anomalous pulmonary venous drainage & + & No & Yes & Alive \\
\hline 5 & Aortic stenosis, mitral incompetence & + & No & Yes & Alive \\
\hline 6 & Ventricular septal defect & + & No & Yes & Alive \\
\hline 7 & Pulmonary stenosis & + & Yes & No & Alive \\
\hline 8 & Atrioventricular septal defect & & Yes & Yes & Died \\
\hline 9 & Ventricular septal defect & & Yes & No & Alive \\
\hline 10 & Ventricular septal defect & & Yes & No & Died \\
\hline
\end{tabular}

